\title{
VOLATILE COMPOSITION OF SOME RED WINES FROM ROMANIA ASSESSED BY GC-MS
}

\author{
MIHAIL MANOLACHE ${ }^{a}$, TIBERIA IOANA POP ${ }^{a}$, \\ ANCA CRISTINA BABEȘ ${ }^{a}$, IULIA-ALEXANDRA FARCAȘ ${ }^{a}$, \\ MARIA LAURA MUNCACIU ${ }^{a}$, ANAMARIA CĂLUGĂR ${ }^{a}$ * EMESE GAL ${ }^{b}$ *
}

\begin{abstract}
Four varietal wines Fetească Neagră, Merlot, Cabernet Sauvignon and Pinot Noir from Romania were submitted to a liquid-liquid extraction with dichloromethane and analysed by gas chromatography-mass spectrometry (GC-MS). A total of 29 volatile compounds were identified and quantified over two periods of ageing. Wines were differentiated by a number of compounds, such as esters, higher alcohols, and lactones. During wine ageing, all chemicals changed in the volatile composition. Most of alcohols and acids (hexanoic and octanoic acids) increased during ageing, while the esters, except ethyl lactate and diethyl succinate, were found in lower concentrations as ageing time increased. Considering all the volatile compounds detected, esters and higher alcohols are the main contributors for Romanian red wines.
\end{abstract}

Keywords: GC-MS, volatile compounds, red wine, liquid-liquid extraction

\section{INTRODUCTION}

Volatile compounds (VOCs) have an important role in contributing to wine aromatic attributes, beverage flavor and its quality [1]. Aroma and flavor compounds are found and released in three distinct categories: 1) they originate from the grapes where they are synthesized; 2) most of them are formed during the process of grape must fermentation, and 3) they result from aging and storage [2, 3]. About 600 to 800 volatile compounds such as alcohols, esters organic acids, aldehydes, ethers, ketones, and terpenes, etc.,

\footnotetext{
a University of Agricultural Sciences and Veterinary Medicine Cluj-Napoca, Faculty of Horticulture, 3-5 Calea Mănăștur str, RO-400372, Cluj-Napoca, Romania

${ }^{\mathrm{b}}$ Babeş-Bolyai University, Faculty of Chemistry and Chemical Engineering, 11 Arany Janos str., RO-400028, Cluj-Napoca, Romania

*Corresponding authors: anamariacalugar1981@gmail.com, emese@chem.ubbcluj.ro
} 
have been identified in wines [4], though the knowledge of the aroma of wines is not a simple task for researchers. Although several hundreds of chemical compounds were identified in grapes and wines, only a few compounds contribute to the organoleptic perception of wine [5]. The groups of volatile compounds have different chemical and physical properties, like polarity and volatility, and their concentrations may vary from few $\mathrm{ng} / \mathrm{L}$ to more than $100 \mathrm{mg} / \mathrm{L}$ [6]. Higher alcohols, acids, and esters are found in large quantities and are important for the sensory properties and quality of wine [7]. Small amounts of higher alcohols are contributing positively to wine quality, while excessive amounts may detract from quality [2]. Higher alcohols are important as precursors for ester formation during aging (bottle or barrel aging). Esters comprise an important family of aroma compounds in wine. Ethyl esters are found in the largest quantities, while acetates, found in a less quantity, contribute to the intensity and quality of wine aroma [8]. These esters identified in wine are found in the grape, but their main origin is from the secondary metabolism of yeasts during fermentation [9]. The ethyl esters of the majority of acids in wine are made during the ageing process [10]. The release of aroma precursors can occur during wine aging, under mild acidic conditions [11]. Fatty acids have been reported to be able to affect the aromatic equilibrium of wines because they are opposed to the hydrolysis of the corresponding esters. Those compounds strengthens wine flavor at low concentration, but at high levels, conferred wine sour and thin tasting [12]. Esters based on ethanol and saturated fatty acids, such as hexanoic and octanoic acids, generally contribute to the 'fruity' or 'wine-like' aroma of wine, their presence even at sub-threshold levels having a possible additive effect [13]. The flavor-active metabolites that have an impact on wine perception are derived from the grapes and from microorganisms during fermentation, as well as from chemical processes during production and maturation [14]. During wine ageing under different conditions, the volatile composition could be changed due to the appearance of some volatiles that could decline the wine aroma quality $[15,16]$. Therefore, the final aroma of aged wines is really complex [17].

Aroma of a wine can be influenced by several factors: grape varietal characteristics [7, 18, 19], light intensity, temperature [12], soil, climate [20, 21], degree of maturation, cultivation practices [22-24]. The winemaking technologies applied (pressing, fermentation temperature, maceration, yeast strain, $\mathrm{SO}_{2}$, wine ageing, and storage) affect the final aroma compounds of wines [25-27]. Moreover, the personality of each wine is due to the infinitely varied combinations and concentrations of the various volatile compounds [28]. 
Qualitative and quantitative characterizations of volatile compounds in wine are performed by GC-MS, as one of the most sensitive techniques for the analysis of volatile compounds in wine [29, 30]. Since wine is a complex matrix, GC-MS is suitable for quantification purposes, using the polar column for separation of the components, due to the fact that is more sensitive for analysis of components present in a low concentration [31]. The volatile compounds are usually extracted by different methods, such as solid-phase extraction [32], solid-phase micro-extraction [33], stir bar sorptive extraction [34], or liquid-liquid extraction methods using organic solvents [35] before the gas chromatographic analysis. There are few data available for the volatile compounds of the international grape varieties grown in Romania and wines, but also for Romanian grape varieties and wines [36-38]. Fetească Neagră is one of the most widespread and economically important cultivars grown in Romania [39]. Previous research has been performed on the volatile composition of the Fetească Neagră wines by Miclean et al., 2010, Antoce, 2012, Palade et al., 2016 [40-42]. Therefore, the aim of the present work was to characterize the main volatile component for the first time of the autochthonous red wine Fetească Neagră grown in two wine regions in Romania and Cabernet Sauvignon, Merlot, and Pinot Noir wines, produced from grape varieties grown in the north-east and south-east regions of Romania.

\section{RESULTS AND DISCUSSION}

The basic composition of the wine was analyzed according to the methods proposed by OIV 2013 and the results are revealed in Table 1.

The ethanol content of the red wine decreased during the 6 months of aging with losses of about $0.3-0.5 \%$, in according with other studies [43].

As shown in Table 1, there was an increase in volatile acidity during barrel ageing, which could be primarily due to the extraction of volatile acids from the oak [44] and to ethanol oxidation. Barrels are the same in coopering methods and are provided by the same tonnellerie, so the barrel type had no influence in volatile acidity. Titratable acidity (Table 1) presented an increase due to the rise in volatile acidity, during the 6 months of ageing this rise, indicating the extraction of carboxylic, phenolic and volatile acids from wood, as suggested by Canas, 2017 [45]. In all wine samples, free and total $\mathrm{SO}_{2}$ content decreased with storage time. The losses of total $\mathrm{SO}_{2}$ during ageing may be attributed to measurable oxygen permeability of oak staves of barrels. The free $\mathrm{SO}_{2}$ and total $\mathrm{SO}_{2}$ values for all wine samples were less or equal with specific limit existing for red wines to $35 \mathrm{ml} / \mathrm{L}$, respectively $200 \mathrm{mg} / \mathrm{L}$, proposed by EU [46]. These parameters were determined in duplicates. 
Table 1. Evolution of the enological parameters of red wines with two periods of ageing ( 6 and 12 months)

\begin{tabular}{|c|c|c|c|c|c|c|c|c|c|c|}
\hline \multirow[t]{2}{*}{$\begin{array}{c}\text { Wine } \\
\text { oenological } \\
\text { parameters }\end{array}$} & \multicolumn{2}{|c|}{$\begin{array}{c}\text { Cabernet } \\
\text { Sauvignon } \\
\text { Dobra } \\
\text { (Satu Mare) }\end{array}$} & \multicolumn{2}{|c|}{$\begin{array}{c}\text { Fetească } \\
\text { Negră } \\
\text { Rătești } \\
\text { (Satu Mare) }\end{array}$} & \multicolumn{2}{|c|}{$\begin{array}{c}\text { Pinot } \\
\text { Noir Rătești } \\
\text { (Satu Mare) }\end{array}$} & \multicolumn{2}{|c|}{$\begin{array}{c}\text { Merlot } \\
\text { Aliman } \\
\text { (Constanța) }\end{array}$} & \multicolumn{2}{|c|}{$\begin{array}{c}\text { Fetească } \\
\text { Neagră } \\
\text { Aliman } \\
\text { (Constanța) }\end{array}$} \\
\hline & 6 & 12 & 6 & 12 & 6 & 12 & 6 & 12 & 6 & 12 \\
\hline $\begin{array}{l}\text { \%alcohol } \\
\text { content } \\
\text { ethanol }\end{array}$ & 112.04 & 112.00 & 113.07 & 13.04 & 113.48 & 113.45 & 14.17 & 14.10 & 13.96 & 112.89 \\
\hline $\mathrm{pH}$ & 3.89 & 3.64 & 3.96 & 3.56 & 3.55 & 3.32 & 3.68 & 3.36 & 3.65 & 3.24 \\
\hline $\begin{array}{l}\text { Total acidity } \\
\text { (g/l acid } \\
\text { tartric) }\end{array}$ & 5.40 & 5.43 & 5.93 & 5.97 & 6.00 & 6.02 & 5.22 & 5.27 & 5.39 & 5.43 \\
\hline $\begin{array}{l}\text { Volatile } \\
\text { acidity } \\
\text { (g/l acid } \\
\text { acetic) }\end{array}$ & 0.45 & 0.48 & 0.54 & 0.59 & 0.51 & 0.54 & 0.62 & 0.68 & 0.70 & 0.75 \\
\hline $\begin{array}{l}\text { Dry extract } \\
(\mathrm{g} / \mathrm{l})\end{array}$ & 33.10 & 31.32 & 33.50 & 29.78 & 35.40 & 32.24 & 33.60 & 31.89 & 34.20 & 30.23 \\
\hline $\begin{array}{l}\text { Non - } \\
\text { reducing } \\
\text { dry extract } \\
(\mathrm{g} / \mathrm{l})\end{array}$ & 30.14 & 28.98 & 29.00 & 27.67 & 31.12 & 29.43 & 32.78 & 30.12 & 31.25 & 29.72 \\
\hline $\begin{array}{c}\text { Free } \mathrm{SO}_{2} \\
(\mathrm{mg} / \mathrm{l})\end{array}$ & 14.89 & 12.56 & 25.00 & 22.76 & 27.50 & 23.69 & 16.64 & 12.45 & 25.05 & 21.76 \\
\hline $\begin{array}{c}\text { Total SO } \\
(\mathrm{mg} / \mathrm{l})\end{array}$ & 25.00 & 19.98 & 60.00 & 55.65 & 60.00 & 54.67 & 67.84 & 61.23 & 111.3 & 98.43 \\
\hline
\end{tabular}

The 29 volatile compounds grouped according to their chemical structure, include 10 alcohols, 11 esters, 5 fatty acids, 1 lactone and 2 other compounds - acetonvanilona, ethyl vanillate, were identified and quantified in red wine samples (Table 2 and Table 3 ). The sub-total concentration of particular classes and their percentage of the total content of volatile compounds were calculated to verify whether the examined wines differentiated in proportions of aroma compounds classes.

Wine volatile compounds, such as esters, acids, and alcohols, are transformed during wine ageing, leading to changes in wine aroma [47].

Interesting similarities were observed in the evolutionary trends of volatile compounds during 6 and 12 months of the aging period. It was noted that volatile compounds possessed different evolution patterns during aging. Some volatiles decreased in the concentration along with the aging period. The majority of esters, alcohols, and acids followed an evolution pattern where an increase in the concentration was observed in 12 months (Table 3) of aging compared with 6 months period (Table 2). 


\section{Alcohols}

Overall, 10 alcohols have been identified in the analyzed red wines (Table 2 and Table 3 ) for the two periods of ageing. The composition of alcohols differed both qualitatively and quantitatively among the wines. The total concentration of the alcohols ranged from $6405.16 \mu \mathrm{g} / \mathrm{L}$ (Merlot from the south-east region) to $9637.64 \mu \mathrm{g} / \mathrm{L}$ (Cabernet Sauvignon from the north-west region) for the wines aged for 6 months, being $10,91 \%$ and $36.06 \%$, respectively, of the total volatile compounds detected at this stage (Table 2). The content of higher alcohols of wines aged for 12 months was ranged from $6878.20 \mu \mathrm{g} / \mathrm{L}$ (Fetească Neagră from the south-east region) to 22515.33 $\mu \mathrm{g} / \mathrm{L}$ (from Cabernet Sauvignon from the north-west region) being $9.74 \%$ and $32.66 \%$ respectively, for volatiles detected at this stage (Table 3 ). The concentrations of alcohols of the total volatile compounds in wines from our study were much lower compared with those reported in French wines 44.98 - $74.52 \%$, in Italian wines 51.15 - 66.61\%, in Spanish wines 46.02 - 57.86\%, and in Polish wines 42.85 - 67.73\% [48].

This volatile fraction was mainly composed of isopentyl alcohol (bitter; harsh), isobutanol - (medicinal, wine-like), 2-phenyl-ethanol (roses, pollen, flowery) and 1-hexanol (floral, green, grass cut; herbaceous, fatty, resinous) as the major components in the overall volatile content of the wines. Our results are in according with those obtain in Italy [49], [50] which reported also higher amounts of 2-phenylethanol and isopentyl alcohol in aroma compound classes in Negroamaro and Primitivo wines.

2,3 - butanediol cannot be expected to appreciably affect sensory qualities of wine, because of its slightly bitter taste, but it may contribute to the body of a wine because of its viscosity and its high content [51]. The amounts of 2,3 - butanediol in wines from our study (1336.68 - 6895.2 $\mathrm{\mu g} / \mathrm{L})$ may be due to the malolactic fermentation or by aeration through barrels staves used for the first time. Similar amounts of 2,3-butanediol were found in Vilana wines in Greece [52]. In contrast with our results, others detected much lower amount of this compound in French, Polish, Italian and Spanish wines [48].

Higher alcohols amounts changed with ageing, for majority an increase could be observed (Table 3 ), perhaps as a result of hydrolysis of the esters or evaporation during wood maturation [53].

\section{Esters}

Because the wine contains a large number of different alcohols and acids, a wide variety of esters could be formed. In our study, 11 esters were detected in the analyzed wines (Table 2 and Table 3). The total concentration of esters ranged from $11116.14 \mu \mathrm{g} / \mathrm{L}$ (Cabernet Sauvignon from the north-west 
region) to $41165.43 \mu \mathrm{g} / \mathrm{L}$ (Merlot from the south-east region) for the wines aged for 6 months, being $42.43 \%$ and $70.43 \%$, respectively, of the total VOCs detected at this stage (Table 2). The content of ester of wines aged for 12 months was ranged from $19220.83 \mu \mathrm{g} / \mathrm{L}$ (Fetească Neagră from the southeast region) to $52467.93 \mu \mathrm{g} / \mathrm{L}$ (Merlot from the south-east region) being $28.31 \%$ and $76.62 \%$ respectively, for volatiles detected at this stage (Table 3 ).

Wine samples show low concentrations of acetate esters and only two were detected (Table 2 and Table 3). They were isoamyl acetate (fresh, banana) and octyl acetate (fruity, candy, pineapple, pear, floral) and they may produce synergistic effects on the overall flavor of wine, as they provide pleasant fruity notes.

Wines from the two regions showed differences in the concentrations of acetate esters. Increases in acetate esters in wine samples have been observed during the ageing of wines or remained stable, these findings being in agreement with other studies [54,55]. Among ethyl esters, the most abundant compounds in wines samples were ethyl hexanoate, ethyl decanoate, and ethyl lactate, the same findings were reported for Italian wines, Spanish wines, Polish wines and French wines [48].

The ethyl hexanoate (green apple; fruity; strawberries, anise note) is a volatile ester produced during fermentation process by yeasts, varied from a minimum of $86.44 \mu \mathrm{g} / \mathrm{L}$ in the samples of Fetească Neagră from south-east of Romania to a maximum of $434.53 \mu \mathrm{g} / \mathrm{L}$ for the same sample after 12 months of barrel aging. For all wine samples, this volatile compound registered an increase in concentration during ageing.

An interesting variability in the analyzed samples was for ethyl decanoate (fruity, grape notes) an ester specific for the alcoholic beverages. The highest quantity was identified in the samples aged for 6 months but decreased over time as wine ages due to spontaneous hydrolysis [16]. Except this trend was for Fetească Neagră wines from the north-west region, ethyl decanoate was not detected in wines aged for 6 months, but found in small amounts in wines aged for 12 months $(9.64 \mu \mathrm{g} / \mathrm{L})$ as shown in Table 3. Also, Merlot wines from the south-east region aged for 12 months (Table 3 ) contained a higher quantity of ethyl decanoate compared with the samples aged for 6 months (Table 2). The presence of esters in higher concentrations in wines from the south-east region compared to those from the north-west region might be explained by the different environmental conditions [38].

Ethyl lactate (lactic, medicinal, raspberry and strawberry) is formed mainly during the malolactic fermentation, in red wines the concentration is higher, the large variation between the wines can be explained by the achievement of this compound during malolactic fermentation [56]. This compound varied from several to almost $24 \mathrm{mg} / \mathrm{L}$ in wine samples (Table 3), the results are comparable with those found in Malbec wines [57]. 
Table 2. Concentrations of free volatile compounds $(\mu \mathrm{g} / \mathrm{L})$ in red wines aged 6 months from Satu Mare and Constanța County $(n=2)$

\begin{tabular}{|c|c|c|c|c|c|}
\hline $\begin{array}{r}\text { Wine } \\
\text { location } \\
\text { Compounds }\end{array}$ & $\begin{array}{c}\text { Cabernet } \\
\text { sauvignon } \\
\text { Dobra } \\
\text { (Satu Mare) }\end{array}$ & $\begin{array}{c}\text { Fetească } \\
\text { neagră } \\
\text { Rătești } \\
\text { (Satu Mare) }\end{array}$ & $\begin{array}{c}\text { Pinot noir } \\
\text { Rătești } \\
\text { (Satu Mare) }\end{array}$ & $\begin{array}{c}\text { Fetească } \\
\text { neagră } \\
\text { Aliman } \\
\text { (Constanta) }\end{array}$ & $\begin{array}{c}\text { Merlot } \\
\text { Aliman } \\
\text { (Constanta) }\end{array}$ \\
\hline \multicolumn{6}{|c|}{ Alcohols $^{a}$} \\
\hline $\begin{array}{l}\text { Isopentyl } \\
\text { alcohol }\end{array}$ & $1282.6 \pm 41.29$ & $2347.3 \pm 18.58$ & $2997.20 \pm 25.36$ & $1562.57 \pm 14.4$ & $1092.89 \pm 15.2$ \\
\hline Isobutanol & $1490.89 \pm 34.34$ & $1579.53 \pm 32.97$ & $948.86 \pm 31.6$ & $115.23 \pm 2.84$ & $104.96 \pm 3.10$ \\
\hline Butanol & - & $10.04 \pm 0.21$ & $7.28 \pm 0.07$ & $3.70 \pm 0.15$ & $2.88 \pm 0.10$ \\
\hline 1-Hexanol & $529.77 \pm 0.39$ & $232.83 \pm 1.46$ & $394.25 \pm 7.89$ & $246.57 \pm 0.07$ & $139.04 \pm 3.25$ \\
\hline 1-Heptanol & $44.66 \pm 0.19$ & $23.84 \pm 0.23$ & $20.24 \pm 0.07$ & $23.91 \pm 0.09$ & $12.55 \pm 0.63$ \\
\hline 2-Nonanol & $45.02 \pm 0.37$ & $10.80 \pm 0.12$ & $30.03 \pm 0.23$ & $30.89 \pm 0.05$ & $17.17 \pm 0.27$ \\
\hline 2,3-butandiol & $3899.17 \pm 9.54$ & $1535.62 \pm 26.9$ & $1455.77 \pm 3.72$ & $4827.00 \pm 1.3$ & $3021.22 \pm 30.4$ \\
\hline $\begin{array}{l}\text { 3-(Methylthio)- } \\
\text { 1-propanol }\end{array}$ & $109.08 \pm 0.16$ & $24.62 \pm 1.68$ & - & $65.99 \pm 0.5$ & $25.29 \pm 0.28$ \\
\hline Phenylmethanol & $85.45 \pm 0.32$ & $116.83 \pm 2.65$ & $243.56 \pm 0.18$ & $53.28 \pm 3.10$ & $101.96 \pm 3.54$ \\
\hline $\begin{array}{c}2- \\
\text { Phenylethanol }\end{array}$ & $2151 \pm 0.18$ & $1279.5 \pm 6.48$ & $2936.5 \pm 35.0$ & $2021.5 \pm 0.50$ & $1887.2 \pm 3.54$ \\
\hline $\begin{array}{c}\text { Total alcohols } \\
(\mu \mathrm{g} / \mathrm{L})\end{array}$ & $9637.64 \pm 86.7$ & $7160.91 \pm 91.4$ & $9033.69 \pm 104.1$ & $8950.64 \pm 23.1$ & $6405.16 \pm 60.3$ \\
\hline $\begin{array}{l}\% \text { of total VOC } \\
\text { concentration }\end{array}$ & 36.06 & 15.46 & 18.62 & 19.36 & 10.91 \\
\hline \multicolumn{6}{|c|}{ Esters $^{b}$} \\
\hline isoamyl acetate & - & $63.86 \pm 1.33$ & \begin{tabular}{|l}
$64.41 \pm 0.10$ \\
\end{tabular} & $41.46 \pm 0.02$ & $34.94 \pm 0.31$ \\
\hline Ethyl caproate & $164.10 \pm 1.92$ & $87.03 \pm 1.48$ & $94.75 \pm 0.50$ & $86.44 \pm 5.38$ & $92.07 \pm 8.85$ \\
\hline Ethyl lactate & $6016.48 \pm 5.28$ & $\begin{array}{c}19080.00 \pm \\
145.5 \\
\end{array}$ & $19039.2 \pm 71.6$ & - & $\begin{array}{c}21130.48 \pm \\
172.4 \\
\end{array}$ \\
\hline $\begin{array}{c}\text { Ethyl-3-hydroxy } \\
\text { butanoate }\end{array}$ & $270.94 \pm 9.01$ & $174.08 \pm 3.33$ & $69.89 \pm 1.44$ & $48.38 \pm 0.46$ & $28.67 \pm 0.44$ \\
\hline Octyl acetate & $370.40 \pm 5.35$ & - & $184.88 \pm 0.11$ & $571.69 \pm 36.1$ & $245.17 \pm 7.3$ \\
\hline Ethyldecanoate & $136.00 \pm 1.69$ & - & $9.58 \pm 0.33$ & $43.07 \pm 0.31$ & $69.08 \pm 1.68$ \\
\hline $\begin{array}{c}\text { Ethylhydrogen } \\
\text { succinate }\end{array}$ & $1198.30 \pm 2.69$ & $2468.44 \pm 14.5$ & $1369.44 \pm 1.41$ & $7120.44 \pm 0.1$ & $\begin{array}{c}11656.29 \pm \\
164.7 \\
\end{array}$ \\
\hline $\begin{array}{c}\mathrm{N} \text {-phenyl } \\
\text { acetamide }\end{array}$ & $85.01 \pm 0.94$ & $31.47 \pm 0.21$ & $29.00 \pm 0.07$ & $10.50 \pm 0.11$ & (2) \\
\hline Diethyl malate & $422.70 \pm 5.69$ & $291.00 \pm 12.04$ & $301.65 \pm 1.87$ & $1204.82 \pm 18.1$ & $359.73 \pm 18.43$ \\
\hline $\begin{array}{c}\text { Diethyl } \\
\text { succinate }\end{array}$ & $696.23 \pm 0.78$ & $917.08 \pm 101.6$ & $998.36 \pm 2.26$ & \begin{tabular}{|c|}
$11323.03 \pm$ \\
35.28 \\
\end{tabular} & $\begin{array}{r}7435.61 \\
\pm 174.64 \\
\end{array}$ \\
\hline $\begin{array}{c}\text { Methyl-4 } \\
\text { hydroxy- } \\
\text { butanoate }\end{array}$ & $1799.98 \pm 1.75$ & $1315.57 \pm 18.97$ & $2611.97 \pm 86.35$ & $517.05 \pm 17.29$ & $113.39 \pm 0.81$ \\
\hline $\begin{array}{c}\text { Total esters } \\
(\mu \mathrm{g} / \mathrm{L})\end{array}$ & $11160.14 \pm 35.1$ & $24428.53 \pm 298.9$ & $\begin{array}{c}24773.13 \pm \\
166.1 \\
\end{array}$ & $\begin{array}{c}20966.88 \pm \\
113.08\end{array}$ & $\begin{array}{c}41165.43 \pm \\
549.58\end{array}$ \\
\hline $\begin{array}{l}\% \text { of total VOC } \\
\text { concentration }\end{array}$ & 42.34 & 52.75 & 51.26 & 45.92 & 70.43 \\
\hline
\end{tabular}


M. MANOLACHE, T. I. POP, A. C. BABEȘ, I.-A. FARCAȘ, M. L. MUNCACIU, A. CĂLUGĂR, E. GAL

Table 2 continued

\begin{tabular}{|c|c|c|c|c|c|}
\hline \multicolumn{6}{|c|}{ Fatty acids ${ }^{a}$} \\
\hline Butyric acid & $74.02 \pm 0.19$ & $164.84 \pm 0.22$ & $200.99 \pm 1.83$ & $246.90 \pm 0.88$ & - \\
\hline Hexanoic acid & $329.55 \pm 0.16$ & $865.39 \pm 18.05$ & $1083.72 \pm 2.40$ & $235.51 \pm 3.01$ & $104.15 \pm 3.08$ \\
\hline Octanoic acid & $167.18 \pm 6.26$ & $218.68 \pm 3.34$ & $182.53 \pm 0.10$ & $175.12 \pm 1.78$ & $63.85 \pm 2.99$ \\
\hline Pidolic acid & - & $100.99 \pm 1.66$ & $58.03 \pm 0.27$ & $76.11 \pm 0.25$ & $101.43 \pm 3.13$ \\
\hline $\begin{array}{c}\text { 5-oxotetra } \\
\text { hydrofuran-2- } \\
\text { carboxylic acid }\end{array}$ & $25.68 \pm 0.64$ & $420.88 \pm 1.94$ & $304.35 \pm 0.28$ & $176.03 \pm 2.47$ & $249.99 \pm 3.42$ \\
\hline $\begin{array}{c}\text { Total fatty acids } \\
(\mu \mathrm{g} / \mathrm{L})\end{array}$ & $596.43 \pm 7.25$ & $1770.78 \pm 25.2$ & $1829.62 \pm 4.88$ & $909.67 \pm 8.39$ & $519.42 \pm 12.6$ \\
\hline $\begin{array}{l}\% \text { of total VOC } \\
\text { concentration }\end{array}$ & 2.23 & 3.82 & 3.77 & 1.97 & 0.89 \\
\hline \multicolumn{6}{|c|}{ Lactones } \\
\hline Butyrolactone & $4963 \pm 0.13$ & $12921 \pm 0.36$ & $12643.5 \pm 0.35$ & $14775 \pm 0.24$ & $\begin{array}{c}10356.21 \pm \\
48.56\end{array}$ \\
\hline $\begin{array}{c}\% \text { of total VOC } \\
\text { concentration }\end{array}$ & 18.57 & 27.90 & 26.06 & 31.96 & 17.65 \\
\hline \multicolumn{6}{|c|}{ Other compounds } \\
\hline Ethyl vanilate & - & $13.47 \pm 0.70$ & $23.65 \pm 0.06$ & $28.30 \pm 0.05$ & - \\
\hline Acetovanillone & - & $19.51 \pm 0.41$ & $27.64 \pm 0.04$ & $25.11 \pm 0.14$ & - \\
\hline $\begin{array}{c}\text { Total other } \\
\text { compounds } \\
(\mu \mathrm{g} / \mathrm{L})\end{array}$ & - & $32.98 \pm 1.11$ & $51.29 \pm 0.10$ & $53.41 \pm 0.19$ & - \\
\hline $\begin{array}{l}\% \text { of total VOC } \\
\text { concentration }\end{array}$ & 0.00 & 0.07 & 0.11 & 0.12 & 0.00 \\
\hline $\begin{array}{c}\text { Total volatiles } \\
(\mu \mathrm{g} / \mathrm{L})\end{array}$ & $\begin{array}{c}26357.21 \pm \\
129.26 \\
\end{array}$ & $\begin{array}{c}46314.20 \pm \\
417.04 \\
\end{array}$ & $\begin{array}{c}48331.23 \pm \\
275.49 \\
\end{array}$ & $\begin{array}{c}45655.60 \pm \\
144.92 \\
\end{array}$ & $\begin{array}{c}58446.22 \pm \\
671.11 \\
\end{array}$ \\
\hline $\begin{array}{l}\% \text { of total VOC } \\
\text { concentration }\end{array}$ & 100 & 100 & 100 & 100 & 100 \\
\hline
\end{tabular}

${ }^{\text {a }}$ Expressed in equivalents of phenyl ethanol

$\mathrm{b}$ Expressed in equivalents of ethyl decanoate

Concentration in microgram per liter $\pm R S D$ (relative standard deviation (\%))

The ethyl esters are among the key compounds in the fruity flavors and they make a general positive contribution to the general quality of wines. Besides the acetate and ethyl esters, some other fatty acid esters of higher alcohols were also identified, including diethyl succinate and diethyl malate (fruity). Diethyl succinate (wine, fruity, caramel) is an ester usually present in the fermented beverages that have been aged for several months.

Our results revealed that the majority of esters, except for ethyl lactate and diethyl succinate, were found in lower concentration as ageing time increased. Ethyl lactate and diethyl succinate showed constant concentration increases that could be caused by chemical esterification during the course of ageing. 


\section{Fatty acids}

The production of fatty acids is dependent on the composition of the must and fermentation conditions [9]. Five fatty acids were identified in all wine samples. The total concentration of those volatile compounds ranged from $519.42 \mu \mathrm{g} / \mathrm{L}$ (Merlot from the south-east region) to $1829.62 \mu \mathrm{g} / \mathrm{L}$ (Pinot Noir from the north-west region) for the wines aged for 6 months, being $0.89 \%$ and $3.77 \%$, respectively, of the total volatile compounds detected at this stage (Table 2). The content of fatty acids of wines aged for 12 months ranged from $793.26 \mu \mathrm{g} / \mathrm{L}$ (Cabernet Sauvignon from the north-west region) to $5838.57 \mu \mathrm{g} / \mathrm{L}$ (Fetească Neagră from the south-east region) being $1.15 \%$ and $8.27 \%$, respectively, for volatiles detected at this stage (Table 3 ).

Volatile components belonging to the group of fatty acids, such as octanoic (rancidity, candy, cheese, animal, spicy, unpleasant) and hexanoic (cheese, greasy) acids, were detected and quantified in the wines and our results are supported by previous findings [58, 59]. Hexanoic acid and octanoic acid were found in all wine samples. In our study, fatty acids might have a positive impact on the aroma of the wines examined since their levels were all far below $20 \mathrm{mg} / \mathrm{L}$ [60].

Table 3 show a differentiated behaviour of fatty acid during ageing. For all wines, it was observed a small increase in medium- and long-chain fatty acids, such as hexanoic and octanoic acids, during ageing. The only except was for Fetească neagră from south-east region, whose concentration in hexanoic and octanoic acids changed slightly when comparing between wines with 6 and 12 months. Short-chain fatty acids, such as butanoic acid, increased his contents during wine ageing.

The level of the dissolved oxygen in wines decreased during ageing and then remained at a low level. This could explain why some volatile alcohols declined, but some aldehydes, acids, and esters were accumulated in the concentration within 6-12 months barrel aging.

\section{Lactones}

A considerable amount of butyrolactone (fruity, coconut-like notes) was found in all red wine samples, due to the fact that all wines were aged for 6-12 months in oak barrels. The presence of butyrolactone in wines could be an indication of a wine's oak ageing.

\section{Other compounds}

Acetovanillone arises from thermal degradation of lignin from oak barrels, although their extraction into wine occurs via different means [45]. Garde-Cerdan et al., 2002 [61] state that acetovanillone was extracted from the wine up to 10 months of ageing and afterward its concentration diminished 
slightly. This finding may be compared with our results, acetovanillona (vanilla) and ethyl vanillate (vanilla, honey), showed an increase during 12 months of ageing, for all wine samples. Moreover, for Cabernet Sauvignon wines from the north-east region and for Fetească Neagră wines from the south east region aged for 6 months, acetovanillone and ethyl vanillate were not detected.

Table 3. Concentrations of free volatile compounds $(\mu \mathrm{g} / \mathrm{L})$ in red wines aged 12 months from Satu Mare and Constanța County $(n=2)$

\begin{tabular}{|c|c|c|c|c|c|}
\hline $\begin{array}{r}\text { Wine } \\
\text { location } \\
\text { Compounds }\end{array}$ & $\begin{array}{c}\text { Cabernet } \\
\text { Sauvignon } \\
\text { Dobra } \\
\text { (Satu Mare) }\end{array}$ & $\begin{array}{c}\text { Fetească } \\
\text { Neagră } \\
\text { Rătești } \\
\text { (Satu Mare) } \\
\end{array}$ & $\begin{array}{l}\text { Pinot Noir } \\
\text { Rătești } \\
\text { (Satu Mare) }\end{array}$ & $\begin{array}{l}\text { Fetească } \\
\text { Neagră } \\
\text { Aliman } \\
\text { (Constanta) }\end{array}$ & $\begin{array}{c}\text { Merlot } \\
\text { Aliman } \\
\text { (Constanta) }\end{array}$ \\
\hline \multicolumn{6}{|c|}{ Alcohols $^{\mathrm{a}}$} \\
\hline $\begin{array}{l}\text { Iso pentyl } \\
\text { alcohol }\end{array}$ & $4384.1 \pm 52.4$ & $2779.46 \pm 21.70$ & $\begin{array}{c}3587.80 \pm 12.3 \\
6\end{array}$ & $2312.2 \pm 32.4$ & $2143.25 \pm 18.65$ \\
\hline Iso butanol & $3906.97 \pm 31.71$ & $1607.67 \pm 5.26$ & $\begin{array}{c}2023.71 \pm 10.4 \\
6\end{array}$ & $118.24 \pm 1.55$ & $458.97 \pm 0.17$ \\
\hline Butanol & $24.08 \pm 1.29$ & $16.19 \pm 0.58$ & $12.99 \pm 0.04$ & $5.26 \pm 0.04$ & $9.10 \pm 0.02$ \\
\hline 1-Hexanol & $570.89 \pm 8.04$ & $250.48 \pm 2.02$ & $431.79 \pm 0.06$ & $462.93 \pm 9.03$ & \pm 0.22 \\
\hline 1-Heptanol & $38.29 \pm 0.93$ & $26.05 \pm 0.63$ & $18.76 \pm 0.04$ & $48.15 \pm 0.34$ & $15.80 \pm 0.34$ \\
\hline 2-Nonanol & $62.14 \pm 0.62$ & $29.82 \pm 0.29$ & $26.61 \pm 0.19$ & - & $28.93 \pm 0.63$ \\
\hline 2,3-butandiol & $6895.2 \pm 10.73$ & $4961.83 \pm 323.11$ & $1336.68 \pm 9.60$ & - & $2993.63 \pm 1.39$ \\
\hline $\begin{array}{c}\text { 3-(Methylthio)- } \\
\text { 1-propanol }\end{array}$ & $114.03 \pm 0.27$ & $32.85 \pm 0.32$ & $64.91 \pm 0.46$ & $90.90 \pm 3.14$ & $53.47 \pm 6.38$ \\
\hline Phenylmethanol & $237.63 \pm 3.36$ & $62.92 \pm 0.26$ & $77.55 \pm 1.50$ & $178.02 \pm 0.16$ & $235.02 \pm 2.87$ \\
\hline 2-Phenyl ethanol & $6282 \pm 0.11$ & $1266.5 \pm 9.68$ & $2398 \pm 0.12$ & $3662.5 \pm 0.45$ & 5.79 \\
\hline $\begin{array}{c}\text { Total alcohols } \\
(\mu \mathrm{g} / \mathrm{L})\end{array}$ & $22515.33 \pm 109.4$ & $11033.77 \pm 363.8$ & $9978.80 \pm 34.8$ & $6878.20 \pm 47.1$ & $8552.96 \pm 36.4$ \\
\hline $\begin{array}{l}\% \text { of total VOC } \\
\text { concentration }\end{array}$ & 32.56 & 17.30 & 16.73 & 9.74 & 12.46 \\
\hline \multicolumn{6}{|c|}{ Esters $^{\text {b }}$} \\
\hline $\mathrm{N}$-amyl acetate & $170.91 \pm 1.73$ & $49.44 \pm 1.69$ & $64.70 \pm 0.57$ & $156.25 \pm 0.46$ & $53.45 \pm 1.87$ \\
\hline Ethyl caproate & $340.79 \pm 12.91$ & $124.30 \pm 3.47$ & $231.13 \pm 0.65$ & $434.53 \pm 6.82$ & $202.34 \pm 0.12$ \\
\hline Ethyl lactate & $6417.48 \pm 8.35$ & $19400.39 \pm 177.23$ & $24418.60 \pm 6.66$ & - & $24164.77 \pm 357.78$ \\
\hline $\begin{array}{c}\text { Ethyl-3-hydroxy } \\
\text { butanoate }\end{array}$ & $737.37 \pm 8.35$ & $31.76 \pm 0.67$ & $62.40 \pm 0.44$ & $126.4 \pm 1.06$ & $43.67 \pm 0.11$ \\
\hline Octyl acetate & $239.12 \pm 1.78$ & $85.50 \pm 5.19$ & $26.36 \pm 0.53$ & $2714.50 \pm 5.91$ & $139.36 \pm 0.17$ \\
\hline Ethyldecanoate & $10.77 \pm 0.21$ & $9.64 \pm 0.32$ & $0.82 \pm 0.03$ & $24.39 \pm 0.31$ & $199.92 \pm 2.66$ \\
\hline $\begin{array}{c}\text { Ethyl hydrogen } \\
\text { succinate }\end{array}$ & $12698.45 \pm 15.83$ & $5468.00 \pm 54.93$ & $3618.67 \pm 0.58$ & $8142.23 \pm 16.26$ & $6125.20 \pm 45.91$ \\
\hline $\begin{array}{l}\text { N-phenyl } \\
\text { acetamide }\end{array}$ & $130 \pm 0.76$ & $9.61 \pm 0.20$ & $13.72 \pm 0.01$ & - & $1912.25 \pm 2.34$ \\
\hline Diethyl malate & $1075.85 \pm 16.53$ & $444.08 \pm 27.84$ & $730.07 \pm 0.44$ & $3223.95 \pm 15.10$ & $1912.25 \pm 2.34$ \\
\hline $\begin{array}{c}\text { Diethyl } \\
\text { succinate }\end{array}$ & $14292.21 \pm 162.94$ & $8457.77 \pm 129.04$ & $2873.12 \pm 0.26$ & $3496.21 \pm 3.78$ & $17506.49 \pm 185.7$ \\
\hline
\end{tabular}


Table 3 continued

\begin{tabular}{|c|c|c|c|c|c|}
\hline $\begin{array}{l}\text { Methyl-4 } \\
\text { hydroxy- } \\
\text { butanoate }\end{array}$ & $4983.96 \pm 8.06$ & $1389.70 \pm 19.53$ & $493.78 \pm 12.75$ & $902.37 \pm 4.42$ & $208.23 \pm 1.15$ \\
\hline $\begin{array}{c}\text { Total esters } \\
(\mu \mathrm{g} / \mathrm{L})\end{array}$ & $41096.91 \pm 237.4$ & $35470.19 \pm 420.1$ & $32533.37 \pm 22.9$ & $19220.83 \pm 54.1$ & $52467.9 \pm 600.1$ \\
\hline $\begin{array}{l}\% \text { of total VOC } \\
\text { concentration }\end{array}$ & 59.63 & 55.68 & 54.57 & 28.31 & 76.62 \\
\hline \multicolumn{6}{|c|}{ Fatty acids $^{a}$} \\
\hline Butyric acid & $73.62 \pm 1.25$ & $334.66 \pm 1.90$ & $333.02 \pm 0.04$ & $490.88 \pm 1.47$ & $43.51 \pm 0.52$ \\
\hline Hexanoic acid & $338.36 \pm 1.42$ & $862.86 \pm 60.55$ & $1500.29 \pm 5.64$ & $736.24 \pm 1.31$ & $284.23 \pm 0.11$ \\
\hline Octanoic acid & $241.75 \pm 0.71$ & $135.87 \pm 2.19$ & $235.08 \pm 0.59$ & $904.19 \pm 4.28$ & $383.19 \pm 12.06$ \\
\hline Pidolic acid & $71.52 \pm 3.11$ & $118.08 \pm 1.59$ & - & $618.51 \pm 0.55$ & $323.41 \pm 2.43$ \\
\hline $\begin{array}{c}\text { 5-oxotetra } \\
\text { hydrofuran-2- } \\
\text { carboxylic acid }\end{array}$ & $68.01 \pm 3.90$ & $743.64 \pm 14.76$ & $1218.87 \pm 0.51$ & $3088.75 \pm 2.72$ & $1685.65 \pm 6.61$ \\
\hline \multicolumn{6}{|c|}{ Table 3 continued } \\
\hline $\begin{array}{c}\text { Total fatty acids } \\
(\mu \mathrm{g} / \mathrm{L})\end{array}$ & $793.26 \pm 10.4$ & $2195.11 \pm 80.9$ & $3287.26 \pm 6.8$ & $5838.57 \pm 10.3$ & $2719.99 \pm 21.7$ \\
\hline $\begin{array}{l}\% \text { of total VOC } \\
\text { concentration }\end{array}$ & 1.15 & 3.44 & 5.51 & 8.27 & 3.96 \\
\hline \multicolumn{6}{|c|}{ Lactones } \\
\hline Butyrolactone & $4409 \pm 2.70$ & $14933 \pm 0.08$ & $13800 \pm 0.14$ & $35791 \pm 120.17$ & $4624.42 \pm 31.23$ \\
\hline $\begin{array}{l}\% \text { of total VOC } \\
\text { concentration }\end{array}$ & 6.38 & 23.41 & 23.14 & 50.69 & 6.74 \\
\hline \multicolumn{6}{|c|}{ Other compounds } \\
\hline Ethyl vanilate & $74.28 \pm 3.19$ & $46.95 \pm 1.59$ & - & $97.01 \pm 0.1$ & $72.15 \pm 1.16$ \\
\hline Acetovanillone & $31.55 \pm 0.90$ & $29.68 \pm 0.30$ & $21.72 \pm 0.05$ & $66.98 \pm 0.14$ & $43.62 \pm 0.62$ \\
\hline $\begin{array}{l}\text { Total other } \\
\text { compounds } \\
(\mu \mathrm{g} / \mathrm{L})\end{array}$ & $105.83 \pm 4.09$ & $76.63 \pm 1.89$ & $21.72 \pm 0.05$ & $163.99 \pm 0.24$ & $115.77 \pm 1.78$ \\
\hline $\begin{array}{l}\% \text { of total VOC } \\
\text { concentration }\end{array}$ & 0.15 & 0.12 & 0.04 & 0.23 & 0.17 \\
\hline $\begin{array}{c}\text { Total volatiles } \\
(\mu \mathrm{g} / \mathrm{L})\end{array}$ & $68920.3 \pm 364.0$ & $63708.7 \pm 866.9$ & $59647.5 \pm 65.3$ & $67892.6 \pm 231.9$ & $68481.1 \pm 691.3$ \\
\hline $\begin{array}{l}\% \text { of total VOC } \\
\text { concentration }\end{array}$ & 100 & 100 & 100 & 100 & 100 \\
\hline
\end{tabular}

${ }^{a}$ Expressed in equivalents of phenyl ethanol

${ }^{b}$ Expressed in equivalents of ethyl decanoate

Concentration in microgram per liter $\pm R S D$ (relative standard deviation (\%))

During aging, the level of the dissolved oxygen in wines decreased and stays at a low level and this could explain why some volatile alcohols declined, but some acids and esters were accumulated in the concentration within 6-12 months barrel aging. 
Of the chemical groups found in the volatile fraction of the red wines sample analyzed, esters were present in the highest number (11), followed by alcohols (10), acids (5), lactone (1). The predominance of volatile compounds belonging to this class of esters, alcohols, and acids has been previously observed by Welke et al., 2012 [62] and Jiang et al., 2013 [12], Ivanova et al., 2013 [3], Arcaria et al., 2017 [63], in different varietal red wines.

\section{CONCLUSIONS}

A total of 29 volatile compounds were determined by GC-MS in red wines produced in Romania. Considering all the detected volatiles, esters and alcohols were the main contributors to the overall volatile composition of the wines, which made up to $30-70 \%$ and $10-35 \%$ of the total level of volatiles, respectively. Wines aged for 12 months contained a higher amount of volatile compounds compared to the wines aged for 6 months. The Romanian red wines were characterized by higher level of esters, alcohols, and lactones. The volatile compounds in red wines aged for two periods of time are strongly marked by a decrease in the concentration of esters as the ageing time gets longer, with only ethyl lactate and diethyl succinate showing an increase. Higher alcohols amounts increased with ageing maybe as a result of hydrolysis of the esters or evaporation. The high amount of butyrolactone in all sampled wines is an indication of the ageing of these wines in oak barrels.

Considering all volatiles detected, esters and higher alcohols are the main aromatic contributor for Romanian wines in both oenological regions.

\section{EXPERIMENTAL SECTION}

\section{Vineyard}

Grapes were collected during the 2016 season, at commercial harvest, in the wine producing areas Dobra and Rătești both located in Satu Mare County (north-west region of Romania) and Aliman, located in the Constanța County, south-east of Romania.

Table 4 shows climatic conditions from the two regions and latitude, longitude and altitude of the areas were determined with the global positioning system GPS apparatus.

In an effort to identify volatile compounds related to grape variety and wine characteristics rather than growing conditions, wine samples were sourced from three commercial vineyards located in the mentioned regions. 
Table 4. Climatic conditions and geographic coordinates of Vitis vinifera L. grapes from Romania investigated in this study

\begin{tabular}{|c|c|c|c|c|c|c|c|c|}
\hline Location & $\begin{array}{l}\text { Vitis vinifera } \\
\text { L. grape variety }\end{array}$ & 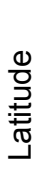 & 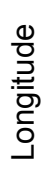 & 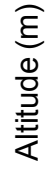 & $\begin{array}{c}\text { Annual mean } \\
\text { temperature } \\
\left({ }^{\circ} \mathrm{C}\right)\end{array}$ & $\begin{array}{l}\text { Mean } \\
\text { relative } \\
\text { humidity } \\
(\%)\end{array}$ & $\begin{array}{c}\text { Annual } \\
\text { mean } \\
\text { rainfall } \\
(\mathrm{mm})\end{array}$ & $\begin{array}{l}\text { Vineyard } \\
\text { exposure }\end{array}$ \\
\hline $\begin{array}{l}\text { Dobra } \\
\text { Satu Mare } \\
\text { County }\end{array}$ & $\begin{array}{l}\text { Cabernet } \\
\text { Sauvignon }\end{array}$ & 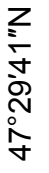 & 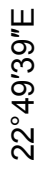 & $\begin{array}{l}\frac{0}{6} \\
\frac{1}{0} \\
\stackrel{m}{r}\end{array}$ & 10.1 & $50-60$ & 623 & $\begin{array}{l}\text { S, } \\
\text { S-W }\end{array}$ \\
\hline $\begin{array}{l}\text { Rătești } \\
\text { Satu Mare } \\
\text { County }\end{array}$ & $\begin{array}{l}\text { Fetească } \\
\text { Neagră, } \\
\text { Pinot Noir }\end{array}$ & 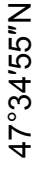 & 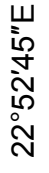 & $\begin{array}{l}\text { ○ } \\
\text { ঠ் } \\
\qquad\end{array}$ & 10.1 & $50-60$ & 623 & $\begin{array}{l}\text { S, } \\
\text { S-E, } \\
\text { S-W }\end{array}$ \\
\hline $\begin{array}{l}\text { Aliman } \\
\text { Constanța } \\
\text { County }\end{array}$ & $\begin{array}{l}\text { Merlot, } \\
\text { Fetească } \\
\text { Neagră }\end{array}$ & 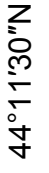 & 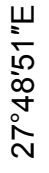 & 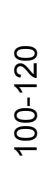 & 11.7 & $40-50$ & 440 & $\begin{array}{l}\text { S, } \\
\text { S-E, } \\
\text { S-W }\end{array}$ \\
\hline
\end{tabular}

\section{Wine samples}

The wine samples consisted in five red wines from two wine regions: Cabernet Sauvignon, Fetească Neagră and Pinot Noir (from Satu Mare north-west of Romania) and Fetească Neagră and Merlot (from Constanța south-east of Romania) were kindly donated by wineries. All the wine samples were from the same vintage, 2016.

All wine samples were fermented in stainless steel fermenters at 20$32^{\circ} \mathrm{C}$ and the malolactic fermentation was performed ten days after the alcohol fermentation. Wines were aged in the same type of oak barrel provided by the same tonnellerie, for 6 months and 12 months. The oaks from species Q.robur were grown in the forests of Arad County. The oak barrels were medium toast $\left(2.5\right.$ hours, toast temperature $\left.-120-160^{\circ} \mathrm{C}\right)$.

All samples were kept at $4^{\circ} \mathrm{C}$ before the analysis.

Oenological parameters were analyzed for two reasons: first, some of them are directly connected with wine quality (volatile acidity and ethanol content), with wine stability ( $\mathrm{pH}$, titrable acidity, levels of tartaric acid, levels of sulphur dioxide); second, they are closely correlated with the extractive capacity of wines. 
All the wines were elaborated and aged in the winery and cellars of Dobra Wine (situated in Dobra - Satu Mare County), Rătești Wine (situated in Rătești - Satu Mare County) and Alira Wine (situated in Aliman - Constanța County).

\section{Chemicals and Reagents}

The reference standards, 2-phenyl ethanol, ethyl decanoate, butyrolactone, isoamyl alcohol and 1-octanol (used as internal standard, IS) were supplied from Fluka. Dichloromethane, used for extraction of volatiles, was purchased from VWR. The standard stock solutions were prepared by dissolving $10 \mathrm{mg}$ of each reference compound in $10 \mathrm{ml}$ of dichloromethane.

\section{Liquid-liquid extraction}

The protocol used by Andujar-Ortiz et al., 2009 [64], was adapted and used for isolation of the volatile compounds from the wine samples. To $50 \mathrm{ml}$ of wine spiked with 1-octanol $(614 \mu \mathrm{g} / \mathrm{L}$ concentration) internal standard was added $20 \mathrm{~mL}$ of dichloromethane and placed in Erlenmeyer flask equipped with a ground stopper. The extraction was carried out under continuous stirring in an ice bath for 30 minutes. Then the mixture was kept for 15 minutes in an ultrasonic bath at the same temperature, to avoid possible formation of an emulsion. After separation, the organic layer was dried on $\mathrm{Na}_{2} \mathrm{SO}_{4}$, evaporated under a nitrogen stream to approximately $200 \mu \mathrm{L}$ volume of the extract. From this solution, $1 \mu \mathrm{L}$ was injected into the GC-MS system. All extractions were carried out in triplicate.

\section{GC-MS analysis}

Analysis of wine volatile compounds was carried out using a Shimadzu QP 2010 PLUS Mass Spectrometer coupled with Gas Chromatograph (Shimadzu) equipped with a Carbowax type column from Agilent, with a dimension $30 \mathrm{~m} \times 0.32 \mathrm{~mm}$ ID and $0.50 \mu \mathrm{m}$ film thicknesses. The carrier gas was $\mathrm{He}(6.0)$ with a flow rate $1.7 \mathrm{~mL} / \mathrm{min}$. The working parameters were: injector temperature $250^{\circ} \mathrm{C}$, the ion source temperature $220^{\circ} \mathrm{C}$, and the interface temperature $250^{\circ} \mathrm{C}$. The column temperature program was conducted as follows: $40^{\circ} \mathrm{C}$ was the initial temperature for $5 \mathrm{~min}$, increasing at a rate of $4^{\circ} \mathrm{C} / \mathrm{min}$ to $220^{\circ} \mathrm{C}$, and holding $220^{\circ} \mathrm{C}$ for 15 . The electron impact (EI) was set at $70 \mathrm{eV}$. A mass range of $35-500 \mathrm{~m} / \mathrm{z}$ was recorded at one scan per second.

\section{Calibration curves}

For quantification, five-point calibration curves were constructed for the following standard compounds: isoamyl alcohol (31-63000 $\mu \mathrm{g} / \mathrm{L})$, butyrolactone $(30-62000 \mu \mathrm{g} / \mathrm{L})$, ethyl-decanoate $(48-15000 \mu \mathrm{g} / \mathrm{L})$ and 2-phenyl ethanol (64$12900 \mu \mathrm{g} / \mathrm{L})$, containing the internal standard (1-octanol). The linearity data 
of the analytical method are presented in Table 5. As can be seen from Table 5 , the linearity is satisfactory in all cases with correlation coefficients $\left(R^{2}\right)$ ranging from 0.9954 (ethyl decanoate) to 0.9991 (butyrolactone).

Table 5. Linear regression data

\begin{tabular}{lllll}
\hline Compound & Intercept & Slope & $\mathbf{R}^{\mathbf{2}}$ & Range $(\boldsymbol{\mu g} / \mathbf{L})$ \\
\hline Butyrolactone & -0.8469 & -0.0152 & 0.9991 & $30-62000$ \\
2-Phenyl ethanol & -0.2280 & -0.0320 & 0.9972 & $64-12900$ \\
Ethyl decanoate & -0.2282 & -0.0015 & 0.9954 & $48-15000$ \\
Isoamyl alcohol & 0.0388 & 0.00038 & 0.9971 & $31-63000$ \\
\hline
\end{tabular}

\section{ACKNOWLEDGMENTS}

Authors are grateful to Mr. Kallos Francisc (Dobra Wine), to Mr. lonut, Gozar (Rătești Wine) and Mr. Marian Ivănescu (Alira Wine) for providing wine samples, and to Mr. Sorin Botoș (Transylvania Bois Tonnellerie) for providing oak barrels in this research.

\section{REFERENCES}

1. E.S. Palomo, E.G. García-Carpintero, M.A.G. Viñas, South African Journal for Enology \& Viticulture, 2015, 36, 117.

2. A. Rapp, H. Mandery, Experientia, 1986, 42, 873.

3. V. Ivanova, M. Stefova, B. Vojnoski, T. Stafilov, I. Bíró, A. Bufa, A. Felinger, F. Kilár, Food Bioprocess Technology, 2013, 6, 1609.

4. M.P. Marti, M. Mestres, C. Sala, O. Busto, J. Guasch, Journal of Agricultural and Food Chemistry, 2003, 51, 7861.

5. P. Polásková, J. Herszage, S.E. Ebeler, Chemical Society Reviews, 2008, 37 (11), 2478.

6. S. Ebeler, Food Reviews International, 2001, 17, 45.

7. J. Bao, Z. Zhang, Molecules, 2010, 15, 9184.

8. C.A. van der Merwe, C.J. van Wyk, American Journal of Enology and Viticulture, $1981,32,41$.

9. P. Schreir, Critical Reviews in Food Science and Nutrition, 1979, 12, 49.

10. R.S. Jackson, "Wine Science: Principles and Applications", Academic Press, San Diego, CA, 1994, chapter 11.

11. A. Bisotto, A. Julien, P. Rigou, R. Schneider, J.M. Salmon, Australian Journal of Grape \& Wine Research, 2015, 21, 194. 
M. MANOLACHE, T. I. POP, A. C. BABEȘ, I.-A. FARCAȘ, M. L. MUNCACIU, A. CĂLUGĂR, E. GAL

12. B. Jiang, X. Zhumei, L. Meijuan, Z. Zhang, Food Research International, 2013, 51 (2), 482.

13. M.A. Amerine, E.B. Roessler, "Wines. Their sensory evaluation", Freeman San Francisco, 1976.

14. S.C. Fairbairn, A.Y. Smit, D. Jacobson, B.A. Prior, F.F. Bauer, South African Journal for Enology \& Viticulture, 2014, 35 (2), 168.

15. L.J. Perez-Prieto, J.M. Lopez-Roca, E. Gomez-Plaza, Journal of Food Composition and Analysis, 2003, 16, 697.

16. D. Liu, R.-R. Xing, Z. Li, D.-M. Yang, Q.-H. Pan, European Food Research and Technology, 2016, 242, 1937.

17. G. Styger, B. Prior, F.F. Bauer, Journal of Industrial Microbiology \& Biotechnology, 2011, 38 (9), 1145.

18. I. Lukić, I. Horvat, Food Technology and Biotechnology, 2017, 55 (1), 95.

19. D. Dimitrov, V. Haygarov, T. Yoncheva, D. Nedelkovski, Journal of Mountain Agriculture on the Balkans, 2017, 20 (3), 187.

20. S.P. Imre, P.A. Kilmartin, T. Rutan, J.L. Mauk, L. Nicolau, Journal of Food Agriculture and Environment, 2012, 10 (2), 280.

21. A. Slegers, P. Angers, K. Pedneault, Journal of Food Chemistry and Nanotechnology, 2017, 3 (1), 8.

22. M. Vilanova, M.P. Diago, Z. Genisheva, J.M. Oliveira, J. Tardaguila, Journal of The Science of Food and Agriculture, 2012, 92, 935.

23. J.M. Meyers, G.L. Sacks, J.E. Vanden Heuvel, HortTechnology, 2013, 23 (5), 581.

24. M. Vilanova, Z. Genisheva, M. Tubio, K. Álvarez, J.R. Lissarrague, J.M. Oliveira, Molecules, 2017, 22, 1500.

25. J.M. Gambetta, S.E.P. Bastian, D. Cozzolino, D.W. Je ery, Journal of Agricultural and Food Chemistry, 2014, 62, 6512.

26. J.J. Rodríguez-Bencomo, M. Ortega-Heras, S. Pérez-Magariño, GónzalezHuerta, Journal of Agricultural and Food Chemistry, 2009, 57, 6383.

27. L. Rolle, V. Englezos, F. Torchio, F. Cravero, S. Rio Segade, K. Rantsiou, S. Giacosa, A. Gambuti, V. Gerbi, L. Cocolin, Australian Journal of Grape and Wine Research, 2018, 24, 62.

28. P. Ribéreau-Gayon, Y. Glories, A. Maujean, D. Dubourdieu, "Handbook of enology. Vol 2: The chemistry of wine: Stabilization and treatments", 2nd Ed. Chichester, Wiley, 2006.

29. P. Polaskova, J. Herszage, S.E. Ebeler, Chemical Society Reviews, 2008, 37, 2478.

30. R. Bleiziffer, S. Suvar, P. Podea, C. Mesaros, M. Culea, STUDIA UBB CHEMIA, 2017, LXII, 3, 123.

31. L. Castro-Vázquez, M.E. Alañón, E. Calvo, M.J. Cejudo, M.C. DíazMaroto, M.S. Pérez-Coello, Journal of Chromatography A, 2011, 1218, 4910.

32. R. López, M. Aznar, J. Cacho, V. Ferreira, Journal of Chromatography A, 2002, 966 (1-2), 167.

33. L. Cai, S. Rice, J.A. Koziel, M. Dharmadhikari, Separations, 2017, 4, 24.

34. D. Caven-Quantrill, A.J. Buglass, Beverages, 2017, 3, 62. 
35. H.S. Canbay, International Journal of Analytical Chemistry, 2017, Article ID 4870671.

36. V. Avram, C.G. Floare, A. Hosu, C. Cimpoiu, C. Măruţoiu, Z. Moldovan, Analytical Letters, 2015, 48, 1099.

37. M. Palade, M.-E. Popa, Scientific Bulletin, Series F. Biotechnologies, 2015, XIX, 174.

38. A.-M. Moroşanu, V.V. Cotea, C.E. Luchian, M. Niculau, C. Colibaba, A.C. Tarţian, BIO Web of Conferences, 39th World Congress of Vine and Wine, 2016, 7.

39. F.D. Bora, A. Donici, A. Ciubucă, E. Postolache, G. Tabaranu, V. Enache,N. Bîrliga, N. Pop, C. Bunea, Bulletin UASVM Horticulture, 2016, 73 (2), 116-125.

40. M. Miclean, A. Naghiu, P. Badea, L.R. Fotescu, Agricultura - Ştiinţă şi practică, 2010, 1-2 (73-74), 68.

41. A.O. Antoce, Revista de chimie, 2012, 63, 9, 859.

42. L.M. Palade, D. Duta, C. Popescu, C. Croitoru, M.E. Popa, Romanian Biotechnological Letters, 2016, 22 (6), 12005.

43. M. Pomar, L.A. Gonzalez-Mendoza, Journal International des Sciences de la Vigne et du Vin, 2001, 35 (1), 41.

44. N. Vivas, A. Lonvaud, Y. Glories, Journal des sciences et techniques de la tonnellerie, 1995, 1, 81.

45. S. Canas, Beverages, 2017, 3 (55), 1.

46. ${ }^{* * *}$, EC Commission Regulation (EC) No. 606/2009 of 10 July 2009 laying down certain detailed rules for implementing Council Regulation (EC) No. 479/2008 as regards the categories of grapevine products, oenological practices and the applicable restriction, Official Journal of the European Union, L 193 (2009), pp. 1-59. EC No 606/2009, Annex I B.

47. R.S. Jackson, "Wine science, principles and applications", 3rd ed., Academic Press-Elsevier, Burlington, USA, 2008.

48. A. Stój, T. Czernecki, D. Domagała, Z. Targoński, International Journal of Food Properties, 2017, 20 (1), 830.

49. M. Tufariello, S. Capone, P. Siciliano, Food Chemistry, 2012, 132, 2155.

50. S. Capone, M. Tufariello, L. Francioso, G. Montagna, F. Casino, A. Leone, P. Siciliano, Sensors and Actuators B, 2013, 179, 259.

51. P. Romano, G. Suzzi, V. Brandolini, E. Menziani, P. Domizio, Letters in Applied Microbiology, 1996, 22, 299.

52. M. Revi, A. Badeka, S. Kontakos, M.G. Kontominas, Food Chemistry, 2014, $152,331$.

53. C. Bayonove, R. Baumes, J. Crouzet, Z. Gunata, Enologia. Fundamentos cientificos y tecnologicos, 2000, 147.

54. J.M. Oliveira, P. Oliveira, R.L. Baumes, O. Maia, Journal of Food Composition and Analysis, 2008, 21, 695.

55. M. Patrianakou, I.G. Roussis, South African Journal of Enology and Viticulture, 2013, 34 (2), 241.

56. M. Gil, J.M. Cabellos, T. Arroyo, M. Prodanov, Analytica Chimica Acta, 2006, $563,145$. 
57. E. Sanchez-Palomo, M. Trujillo, A. García Ruiz, M.A. González Viñas, Food Research International, 2017, 100, 201.

58. R. Perestrelo, A. Fernandes, F.F. Albuquerque, J.C. Marques, J.S. Camara, Analytica Chimica Acta, 2006, 563, 154.

59. C. Coetzee, W.J. du Toit, Food Research International, 2012, 45 (1), 287.

60. S. Lafon-Lafourcade, C. Geneix, P. Ribéreau-Gayon, Applied and Environmental Microbiology, 1984, 47, 1246.

61. T. Garde-Cerdan, D. Torrea-Goni, C. Ancin-Azpilicueta, Australian Journal of Grape and Wine Research, 2002, 8 (2), 140.

62. J.E. Welke, V. Manfroi, M. Zanus, M. Lazarotto, C.A. Zini, Journal of Chromatography A, 2012, 1226, 124.

63. S.G. Arcaria, V. Caliaric, M. Sganzerla, H.T. Godoya, Talanta, 2017, 174, 752.

64. I. Andujar-Ortiz, M.V. Moreno-Arribas, P.J. Martín-Álvarez, M.A. Pozo-Bayón, Journal of Chromatography A, 2009, 1216, 7351. 